\title{
Exploring the Factors Responsible for Delay in Delivery of Justice in India
}

\author{
Hiranmaya Nanda ${ }^{1}$, Shyamantak Misra ${ }^{2}$ \\ ${ }^{1}$ Assistant Professor, Faculty of Legal Studies, Siksha 'O'Anusandhan University, Bhubaneswar-751003, Odisha, \\ India, ${ }^{2}$ Research Scholar, KIIT School Of Law, Bhubaneswar-751004, Odisha
}

\begin{abstract}
Albert Einstein once said in relation to justice that, "in matters of truth and justice, there is no difference between large and small problems, for issues concerning the treatment of people are all the same". The Preamble of the constitution of India states that,"We, the People of India having solemnly resolved to constitute India into a Sovereign, Socialist, Secular, Democratic, Republic and to secure to all its citizens; Justice, social, economic, political;Liberty of thought, expression, belief, faith and worship;Equality of status and opportunity; and to promote among them all;Fraternity, assuring the dignity of the individual and the unity and integrity of the nation." But still after so many years of Independence we have several rules, regulations and mechanisms but those are not adequate to give justice. The establishing father of our constitution placed Justice at the highest level and India is considered to be the largest democracy still we are not getting fair justice. It is a still remain a demand and need to be resolved soon.
\end{abstract}

Keyword: Delay, Justice, Judiciary, Case Backlogs, Pendency.

\section{Introduction}

The Judiciary of India time and again emphasized the significance of the timely delivery of justice. The Supreme Court of India made it eloquent many years ago that "speedy trial is of essence to criminal justice and there can be no doubt that the delay in trial by itself constitutes denial of justice ${ }^{\prime \prime}{ }^{1}$ In this research article the author after having extensive review of literature has identified and discussed with the help of supporting case laws and views of the judiciary few factors for causing delay in delivery of justice. They are as follows:

1. Delay in disposing cases is a hindrance to good governance, moral integrity and detoriation in standard of public life.

\section{Corresponding Author:}

\section{Dr. Hiranmaya Nanda}

Assistant Professor, Faculty of Legal Studies, Siksha

'O' Anusandhan University, Bhubaneswar-751003,

Odisha, India

e-mail: hiranmayananda@soa..ac.in,

Mob.: 9861057452
2. Practicing Advocates are the principal agents in causing the delay in delivery of justice.

3. Procedural laws create the scope for delay in disposal of cases.

4. Lack of adequate infrastructure (both physical and man power) is responsible for delay in disposal of cases.

5. Justice delivery system and rights of the individual are not supplementary to each other.

Good governance, moral integrity and detoriation in standard of public life: The first contention which states that, "Delay in disposing cases is a hindrance to good governance, moral integrity and detoriation in standard of public life." There is a famous quote that, "Justice delayed is Justice denied". This quote has no meaning if it cannot be given in proper time. At the same time, it is exposes that, if justice cannot be rendered on time what would be the use of such a multifaceted judicial system. Justice V D Tulzapurkar of the Supreme Courts has observed that, "if an independent judiciary is regarded as the heart of a republic, then the Indian republic is at present suffering from serious hear aliment. 
In fact, the superior judiciary of the country has of late been under constant onslaughts, external as well as internal which are bound to cripple the health, welfare and progress of our body politic, as an ailing hear cannot ensure vigorous blood supply for the sound health of its people." Thus a very perilous question arises is the faith in judiciary which is being condensed by the public because it affects the governance and standard of public life.

In the words of Dr. Cyrus Das "Justice is a consumer product and must therefore meet the test of confidence, reliability and dependability like any other product if it is to survive market scrutiny. ${ }^{2}$ It exists for the citizenry, 'at whose service only the system of justice must work'. Judicial responsibility, accountability and independence are in every sense inseparable. They are and must be, embodied in the institution of the judiciary." Now a day to get justice has become a dream of a litigant. Even though he gets it, it is not in his life, it may come after his life. This syndrome of getting justice is taking the judiciary far away from the faith and public life and creating a hindrance for good governance. In the landmark case, popularly known as Uphaar Tragedy Case ${ }^{3}$, it took six years to establish that, 59 people have lost their life and more than 100 people have injured out of criminal negligence on the part of the cinema management and the Delhi Government. There are series of cases where prolonged delay defeats justice. Some of them are, in Safdar Hasmi Murder Case, for example, who was killed by political opponents, the criminals were punished after a long 15 years. In Tanduri Murder Case ${ }^{4}$, the accused a Delhi Congress Leader Susil Sarma was convicted with death sentence after long 8 years 6 months. In Model Jesicalal Murder Case and Madhumita Sarma Murder Case, the accused persons were punished and justice rendered to the victims after a long legal scuffle.

Role of Practicing Advocates: The next important contention is "Practicing Advocates are the principal agents in causing the delay in delivery of justice." The role of lawyers is the most imperative aspect in the justice delivery system. The strength and the promises of these legal professionals can make a revolution in the whole set-up. Regrettably, they are prominently responsible for triggering delay in the justice delivery system. There are many reasons such as "firstly they are not precise; they indulge in lengthy oral arguments just to impress their clients,secondly they take adjournments on frivolous grounds. The reasons range from death of the distant relative to family celebrations. With every adjournment the process becomes costly for the court and for the litigants; but the Lawyers get paid for their time and appearance. More often than not, lawyers are busy in another court. They have taken up more cases than they can handle, hence, adjournments are frequently sought. Thirdly many times it is seen that, lawyers do not prepare their cases. A better preparation of the brief is bound to increase the efficiency of the system. Fourthly,it is a trend that lawyers often resort to strikes. The reasons could be any-it ranges from misbehaviour with their colleague both inside court and outside the court to implementation of some enactment. The strike by lawyers against the decision of the government to enforce an amendment in the Civil Procedure Code is an example. This was very unfortunate because the main objective behind these amendments was to curtail delays in disposal of cases. However, the Supreme Court's Judgement in Harish Uppals $v$ Union of India, ${ }^{5}$ that lawyer had no right to go on strike or give a call for boycott not even a token strike, will certainly discourage the lawyer to go on strike unless they really had a strong cause." Gandhiji has also in several times given light in these issues, in his words "throughout my career at the bar I never once departed from the strictest truth and honesty. The first thing which you must always bear in mind, if you would spiritualize the practice of law, is not to make your profession subservient to the interests of your purse, as is unfortunately but too often the case at present, but to use your profession for the service of your country. The fees charged by lawyers are unconscionable everywhere. I confess, I myself have charged what I would now call high fees. But even whilst I was engaged in my practice, let me tell you I never let my profession stand in the way of my public service. And there is another thing I would like to warn you against. In England, in South Africa, almost everywhere I have found that in the practice of their profession Lawyers are consciously or unconsciously 'led into untruth for the sake of their clients. An eminent English Lawyer has gone so far as to say that it may even be the duty of a lawyer to defend a client whom he knows to be guilty. There I disagree. The duty of a lawyer is always to place before the judges and to help them to arrive at, the truth, never to prove the guilty as innocent (Young India, 22-12-1927).”Lord Denning also observed that, "the real reason for delay of lawyers is not slackness or dilatoriness, They are as a class most hardworking of all professional men. It often lies in their choice of priorities. Each case is important and must be dealt with. Each letter must be answered the same day 
or at any rate the next. A sudden call puts something else out of mind(Due Process of Law, 1980 edn. p.89)." Therefore, the need of the hour is that, the lawyers must prove themselves to be the duty bound citizen of India by curing the diseases that are spread in the judiciary.

Old Procedural laws: Another important contention is "Procedural laws create the scope for delay in disposal of cases." There are mainly two types of laws Substantive laws and Procedural Laws. The Substantive laws express the rights and liabilities. Nonetheless the procedural laws provide the instrument to implement these rights and liabilities. There are many laws still in force which are drafted since more than hundred years back. With present pace of the time and society those old laws are not getting their momentum to dispense and creating the biggest blockages in the whole judicial process. Therefore, the valuable time of the court is wasted on the arguments of jurisdiction, cause of action, sufficiency of notice, amendments of plaint and other procedural matters. The Law Commission of India has also time and again have highlighted this major problem through its $14^{\text {th }}, 27^{\text {th }}, 41^{\text {st }}, 48^{\text {th }}$, $54^{\text {th }}, 71^{\text {st }}, 74^{\text {th }}, 77^{\text {th }}, 79^{\text {th }} \& 144^{\text {th }}$ reportsfor necessary reforms in the legislations. Moreover, there are certain difficult terms used in the legislation which is difficult to interpret and understand. Sometimes the judiciary takes time to construct the actual meaning of the term used in the legislation. Hence procedural laws need to be simplified, howsoever good the substantive laws may be to define the rights and liabilities but it won't be fruitful if procedural rules are not simplified. The complexity and rigidity of the procedural laws are the pivotal reason the delay in judicial process. Our varied philosophies, languages,customary practises, religions, apparent in a variation of cases create an intimidating mission before the Judiciary. Adding to it, the statutes are so abundant and slackly drafted, ambiguous and capable of a manufacturing hundreds of interpretations.

Inadequacy of Infrastructure: Further, it is to be noted that,"Lack of adequate infrastructure (both physical and man power) is responsible for delay in disposal of cases." The next factor for delay is the inadequacy of judicial infrastructure in physical as well as in the judicial human resources. From the Ministry of Law and Justice, the data published which evident that, before the Supreme Court of India the approved strength is 31 but 25 numbers of Judges are working creating 6 vacant posts, in all the high courts the approved strength is 1079 but only 676 numbers of judges are working creating 403 numbers of vacant posts (Ministry of Law and Justice, Report Published, Vacancy as on, 01.02.2018). This crisis in judiciary is rising from time to time. Many times it has been advocated by law commission reports and through judicial statistics of annual reports, Judicial reform committees that, the strength of the judiciary can be increased by filling up the vacant post and also recruiting more numbers of judges to deal with overloaded case docket. But in a situation where even the prevailing approved strength is not filled to the maximum then obviously there will be a docket explosion with backlog of cases. It would be relevant to mention that as per the Constitutional structure of India, the selection and recruitment of judges in subordinate courts is the responsibility of State Governments and High Courts.

The Supreme Court has discussed and delivered in a series of cases highlighting this subject. This includes. All India Judges Association Case, where the Supreme Court directed that,"the number of judges should be increased, in the first instance by filling up the existing vacancies followed by an increase in the judge strength in a phased manner." In an another case, Malik Mazhar Sultan Case, the Supreme Court "devised a process and time schedule to be followed by the High Courts and State Governments for the filling up of judicial vacancies." The Supreme Court has issued a direction in the Brij Mohan Lal Case demanding that 10\% added posts should be generated in the subordinate courts of judiciary.

The next vitiating element under this hypothesis is judicial infrastructure. The judiciary in India, mainly the subordinate judiciary are facing more trouble by existing infrastructure they are provided for dispensing of justice. As per the statistics collected from the various High Courts (As of June, 2014), there were 15,419 numbers of court halls or court rooms available for district and subordinate judiciary. Adding to it, 1003 numbers of court rooms were accessible in hired buildings. Now it is high time to relocate adequate judicial infrastructure as per the need system. This necessity is closely connected to the allocation of budgetary planning for the judiciary. The state is also required to make some eye marked steps by making judiciary even more powerful.

Rights and Justice: It is pertinent to mention here that,"Justice delivery system and rights of the individual are not supplementary to each other." The justice delivery system is dependent upon the 
governance of a country. This 'governance' literally means steering. It refers to the processes and systems by which an organization or society operates; the processes by which decisions are made that define expectations, grant power, or verify performance. The duty is not only with judiciary but it also with the legislatures and the executives. A litigant in the whole process got squeezed and ruined by the intimidating factors. Former Chief Justice P N Bhagwati has said that, "I am pained to observe that the judicial system in the country on the verge of collapse. Our judicial system is crashing under the weight of arrears. It is trite saying that justice delayed in justice denied. We often utter this platitudinous phrase to express our indignation at the delay in disposal of cases but this indignation is only at an intellectual and superficial level. Those who are seeking justice in our own Courts have to wait patiently for year and years to gets justice. They have to pass through the labyrinth of one Court to another until their patience gets exhausted and they give up hope in utter despair. The only persons who benefit by the delay in our Courts are the dishonest who can with impunity avoid carrying out their legal obligations for years and each affluent person who obtains orders and stays or injunctions against Government and public authorities and then continues to enjoy the benefits of such stay or injunction for years, often at the cost of public interest."

The constitutional mandate of safeguarding to all its citizens justice, social, economic and political, as guaranteed by the Preamble of the Constitution cannot be appreciated unless the three wings of the government i.e. legislature, executive and judiciary join together to find ways and means for providing to the citizens equal access to its justice delivery system. It is very common that in a criminal case to drag on for years the accused travels from the zone of "anguish" to the zone of "sympathy". The witnesses are either won over by muscle or money power or they become sympathetic to the accused. As a result, they turn hostile and prosecution fails which certainly defeats the justice to the victims. Judiciary today is more deserving of public confidence than ever before. The judiciary has a special role to play in the task of achieving socio-economic goals enshrined in the Constitution while maintaining their aloofness and independence. The whole justice delivery system should be aware of the social changes in the task of achieving socio-economic justice for the people so that there will be reciprocity in rights and justices.

\section{Conclusion}

Justice-social, economic and political is a preambular principle of the Constitution of India. The pledge of equality before the law and equal protection of law lies at the spirit and heart of the judicial administration system. The judiciary is a co-equal stem of governance within the framework of the constitution and the courts are formed not only to deliver judgments or to adjudicate disputes between disputant parties, but also often designate normative doctrine in which institutions are bound by. These doctrines are not merely formulated, but recurrently redefined and adapted to suit changing times, even while assuring that, the hub Constitutional morals are avowed.

Ethical Clearance: Not required, as the research article is based on origin of factors responsible for delay in delivery of justice. The research is doctrinally undertaken.

\section{Source of Funding: Self}

\section{Conflict of Interest: Nil}

\section{References}

1. Hussainara Khatoon v. State of Bihar. AIR. 1979. p. 1364.

2. Krishna O. Structural Reforms for Overcoming Delays in Justice Delivery. Journal of Constitutional Law and Jurisprudence. 2018 May 28;1(1):32-41.

3. Assn. of Victims of Uphaar Tragedy v. Union Of India, And Ors. ACJ. 2003. p. 1631.

4. State v. Sushil Sharma. CriLJ. 2007. p. 4008

5. Harish Uppals v. Union of India. AIR. 2003. p. 739.

6. Singh M. Delay in judicial proceedings causes and remedies.

7. Khan AU. Delays, costs and glorious uncertaintyhow judicial procedure hurts the poor. litigation. 2000;4:4. 